\title{
THE JUDGE IN AN EVOLVING SOCIETY
}

\author{
Lord Cooke of Thorndon*
}

In this address, given to Judges and Judicial Officers of the High Court of Hong Kong on 17 December 1997, Lord Cooke speaks of the development of a common law of the world with particular reference to the Basic Law of Hong Kong.

Chief Justice, Chairman of the Judicial Studies Board, and other friends in the law:

When Chief Justice Li suggested over lunch in the House of Lords in October that I might find it appropriate to give a talk to this distinguished gathering, the title I suggested on the spur of the moment was that now appearing above. It might have been better to think longer before settling on the title. In London I explain to friends that, since retirement from judicial office in New Zealand, I sit from time to time in various developing countries, such as Samoa, Fiji and the United Kingdom. This can pass for a joke, but it is in fact the literal truth. Samoa has been independent since 1962 only. On United Nations insistence, it has a Constitution including both Western-style human rights and indigenous customs and traditions in a blend posing unique problems for the Courts: for example is banishment from the village constitutional, justifiable in the light of the human right to freedom of movement? Fiji has its own distinctive social structure, with the Indian population, not far short in numbers of the indigenous Fijians, being key contributors to the economy. In the last decade two military coups and constitutional changes, including again the introduction of human rights provisions, have presented the Courts there with a different set of issues. In the United Kingdom development is proceeding at a dramatic pace: Scottish devolution to a large degree; Welsh devolution on a lesser scale; at long last partial incorporation of the European Convention on Human Rights into domestic law; the proposed abolition of the right of hereditary peers to sit and vote in the House of Lords. In constitutional terms, all this adds up to more than evolution. It approaches revolution.

* Lord Cooke of Thorndon practised at the New Zealand Bar from 1955 to 1972. He was appointed a Judge of the Supreme Court of New Zealand in 1972 and was President of the New Zealand Court of Appeal between 1986 and 1996. He was created Baron Cooke of Thorndon in 1996 and for part of each year he sits in the Appellate Committee of the House of Lords and the Judicial Committee of the Privy Council. 
And now Hong Kong, uniquely, different again. Restoration since 1 July this year only to its old sovereignty, but under the constitutional rubric of 'one country, two systems'; the essentials of the Hong Kong legal system as established in the former British colony guaranteed for fifty years by an initial Sino-British Joint Declaration, followed by the Basic Law of the Special Administrative Region of the People's Republic of China. I have read, re-read and read again the Basic Law, with a mounting admiration for the skill of the negotiators and drafters. No doubt, as with any other legal document, questions will emerge for the Courts as it falls to be tested against the issues created by unfolding events; yet one's overriding impression at this stage is that - despite or perhaps because of the tensions which sometimes accompanied the work - the greatest credit is due to both the United Kingdom and the People's Republic of China for what their representatives have jointly achieved.

So each of the jurisdictions in which at present I happen to have the privilege of judicial work from time to time is demonstrably that of an evolving society. Indeed, as already suggested, if anything that is an understatement. One does not collect jurisdictions like postage stamps, and the possibilities of any increase at all in my own modest collection are by no means evident, but it seems safe to say as a matter of general knowledge that virtually all other societies are also evolving. The problems are different. The role of the Judge, though, is almost everywhere the same: or at least it ought to be.

Roscoe Pound, the American jurist, was one who spoke of the judicial function as social engineering. That is a description carrying suggestions (perhaps unintended) which I would respectfully reject. It is not the role of the Judge to mould society. Other forces lie at the root of social change. In that regard, as in most others, the Judge has at best an identifying and balancing function. The first requirements of a Judge are integrity and impartiality. The second requirements are also integrity and impartiality. Devotion to those partly elusive values and qualities must be paramount. After them, and handmaids to them, are professional learning and expertise, and the otherwise undefinable quality that we call judgement. The outstanding English-speaking Judges of the latter part of this century exemplify the desirable combination of gifts - such Judges as Reid, Denning and Wilberforce in the United Kingdom, Brian Dickson in Canada, William Brennan in the United States, Mason in Australia - and how glad I am to serve on the same panel here as Sir Anthony. Of the Judges whom I have taken as outstanding examples some may be seen as especially innovative, Lord Denning being the most obvious candidate for this description, but the description is strictly a misnomer. No more than any of the others did Denning find his inspiration in his own breast, in visions vouchsafed to him only. He drew deep from the wells of precedent - naturally for him, with his Hampshire roots and his editorship of Smith's Leading Cases, English precedents. If he seemed to create new law, as plainly he did seem to do not infrequently, that was because he discerned in the judgments of his forerunners underlying principles, and 
wrought their logical extensions or syntheses, expressed with an endearing simplicity of language. I believe, however, that he would not think of himself as a social engineer: not as one who altered people's lives, but as one who laboured to ensure that they got better justice as they lived their lives.

How can we relate the foregoing approach to Hong Kong specifically? In that light the present talk is premature. It would be presumptuous and unwise for me to proffer opinions about Hong Kong legal issues before any experience of grappling with them here at first hand. Writing a few Privy Council judgments in the last stages of the colonial era, and joining in some others, is not enough to justify pontification to this knowledgeable audience. Authorship of Chan Wing-Siu ${ }^{1}$ and Fok Lai Ying ${ }^{2}$ does not qualify one for omniscience. What it is more practicable to do, and what is not irrelevant, is to say a little about a theme which has increasingly drawn me, although it involves peering into the future far more than fifty years ahead.

It chances that I first talked about this theme two years ago at a conference in Melbourne to mark Sir Anthony Mason's retirement as Chief Justice of Australia. My paper was called The Dream of an International Common law. A fortnight ago, in the grand India Council Chamber at the Foreign Commonwealth Office in King Charles Street, it became incumbent to return to the theme before an audience of past and present Rhodes Scholars. This time the paper was called, more boldly, The Common Law of the World. So you will infer that I gained a little in confidence over the two years. Time had not stood still - even if in the Foreign Office itself that appeared to be the case, for the clock in the chamber as the lecture began at 6.10 pm showed 12.32, continued to show that when the lecture finished 45 minutes later, and remained there when the Christmas party was held last Thursday evening. The reason for this I have been unable to discover - no more than inertia after the loss of Empire, or some moment in Imperial history of undying significance? Or even the lack of a key or an experienced winder of elderly clocks?

The title of the India Council Chamber lecture was avowedly proleptic. No one suggests that there is yet a common law of the world. It is many, many years ahead. But that it is ahead I am reasonably confident. In at least three main areas, one can see clear evidence of progress in that direction.

First, interaction between national jurisdictions in the use of precedents, a form of cross-fertilisation. It may be illustrated by what is happening in England. On the whole the common law of England has evolved in a markedly insular way, and there are still

1 Chan Wing-Siu v The Queen [1985] AC 186. For subsequent English case law, see R $v$ Powell [1997] 4 All ER 545

2 Fok Lai Ying v Governor in Council (1997) 7 HKPLR 327. 
many English lawyers who believe that English Judges are gifted beyond all others. But then they might think that English cricketers are gifted beyond all others, but for the evidence of test matches against other countries, comparable evidence being necessarily unavailable in any judicial arena. Insularity in legal development is now, though, becoming distinctly less noticeable. In Donoghue $v$ Stevenson $(1932)^{3}$ only two overseas cases were mentioned in the speeches, both from New York, Cardozo J duly honoured. Whereas the speech of Lord Goff of Chieveley in White $v$ Jones (1995) ${ }^{4}$ cites authorities from, inter alia, Germany, France, The Netherlands, Canada, the United States, Australia, Israel and New Zealand. Donoghue $v$ Stevenson, as to a manufacturer's duty of care to an ultimate consumer, and White $v$ Jones, as to a solicitor's duty of care to the intended beneficiaries of a client's will, are cases that may fairly be compared. They illustrate a difference of judicial technique which reflects an evolving society.

It is noteworthy that the Basic Law of Hong Kong specifically envisages a somewhat similar process. The Courts of the Special Administrative Region are required by article 84 to adjudicate in accordance with articles 8 and 18, which bring in the common law; and it is expressly provided that they 'may refer to precedents of other common law jurisdictions.' Presumably this would not prevent even wider reference to overseas precedents when assistance may be gained from them, but the emphasis is undoubtedly on the common law, and not to the common law as declared in England only. You will be aware that in England itself it has now been established by Privy Council decisions that there may be perfectly legitimate variations in the common law to take into account local circumstances. For Hong Kong, even as a colony, so much was recognised by Lord Diplock in his judgment in de Lasala $v$ de Lasala $(1979)^{5}$ and other recognitions include Australian Consolidated Press Ltd $v$ Uren $(1967)^{6}$ for Australia and Invercargill City Council v Hamlin $(1996)^{7}$ for New Zealand. Naturally there is likely to be less variation in elementary commercial law, where certainty and predicability are especially important goals, which is part of the raison d'étre of the composition of the Court of Final Appeal. The two cases last mentioned are tort cases.

Even in the field of commercial law, and even in highly developed national legal systems, certainty is seldom completely attainable. Hence much of the significance of the second main area in which one sees progress being made towards a common law of the

3 [1932] AC 562. Itself a Scots case!

4 [1995] 2 AC 207.

5 [1980] AC 546.

6 [1969] 1 AC 590.

7 [1996] AC 624. 
world. This is the gradual development of what is called by some the new lex mercatoria, and is otherwise known by various descriptions such as general principles of international commercial law. The concept has its critics, and influential ones, but steadily it appears to be gaining acceptance. It is used quite commonly in international contracts providing for arbitration of disputes or containing choice of law clauses. Thus in Channel Tunnel Group Ltd v Balfour Beatty Construction Ltd (1993) ${ }^{8}$, the House of Lords adjudicated, apparently without difficulty and certainly without any surprised comment on this feature, on a contract expressed to be governed by:

The principles common to both English law and French law, and in the absence of such common principles by such general principles of international trade law as have been applied by national and international tribunals. Subject in all cases, with respect to the works to be respectively performed in the French and in the English part of the site, to the respective French or English public policy (ordre public) provisions.

And, possibly of regrettable relevance in the current economic climate in South-east Asia, international development bank loans are commonly made under contracts containing similar terms. There is even competition in drafting codes of these principles, as witness Principles of European Contract Law, published by the Commission on European Contract Law (Part I in 1995, Part II scheduled for 1998), and The Unidroit Principles for International Commercial Contracts, published in 1995 by the Institute of International Business Law and Practice (an International Chamber of Commerce emanation). ${ }^{9}$

The last of the three main areas is the great one of human rights, encapsulated at the most general level in the Universal Declaration of Human Rights. National documents of a constitutional nature containing human rights affirmations may be said to be legion. It is fashionable to have one. Everybody knows that all too often these are more castles in the air than realities on the ground. They are there nonetheless, and they must in time have a potent influence. The latest convert is the United Kingdom itself, where the partial incorporation of the European Convention is expected to have a transforming effect. We shall see. It is only partial incorporation, for the British Courts will be unable to override primary legislation if it cannot possibly be interpreted as consistent with the Convention rights. The overriding will remain reserved to the European Court of Human Rights in Strasbourg. The British Courts will be able nevertheless to make declarations of incompatibility: and a fast-track procedure for amending the primary legislation in consequence is furnished. Arguably this development owes less to idealism

8 [1993] AC 334.

9 Also published by Unidroit, Rome, 1994. 
than to disquiet at the United Kingdom's record at the hands of the Strasbourg Court. It is still to be applauded as a most notable advance for the human rights cause.

As indeed is the Hong Kong Basic Law itself. Its provisions safeguarding individual human rights are impressive. They are of three chief categories. First, by virtue of articles 8, 18 and 84, the Bill of Rights Ordinance, including the Bill of Rights itself, remains in force. Second, article 39 requires implementation of the International Covenants on Civil and Political Rights and on Economic, Social and Cultural Rights and the international labour conventions as applied to Hong Kong. Together the articles just mentioned import a sweeping range of rights: a range which could astonish new readers. Third, the Basic Law affirms directly a variety of rights, such as the equality of all Hong Kong residents before the law (article 25); the right to vote and stand for election in accordance with law (article 26); freedom of speech, of the press, and of publication; freedom of association, assembly, procession, demonstration; freedom to form and join trade unions and to strike (article 27); inviolable freedom of the person, security against arbitrary or unlawful arrest, detention or search, the prohibition of torture (article 28); the inviolability of the home and prohibition of unlawful or arbitrary search (article 29); privacy of communications, with a limited reservation in aid of the detection of crime (article 30); freedom of movement and travel (article 31); freedom of conscience and religion belief and choice of occupation (articles 32 and 33); the right to confidential legal advice, access to courts and choice of lawyers, and to judicial remedies, including the right to institute court proceedings against executive authorities (article 35); the right to social welfare in accordance with law (article 36); freedom of marriage (article 37). Even that list is not exhaustive. Subject to limited exceptions (see particularly articles 19 and 23) the Basic Law appears to give protected constitutional status to all these rights, free from curtailment (see articles 11 and 159). Subject again to a limited exception, all these rights will fall to be safeguarded by the Hong Kong judiciary in exercise of the Special Administrative Region's high degree of autonomy (see inter alia articles 2, 39, 82, 85, 158).

Certainly there are some qualifications on the protected rights, but bearing in mind that the Basic Law has to be read as a whole it may be that in this context these do not have as much scope as critics sometimes suggest. Examples may bring this out. It is true that the power of amendment of the Law is vested in the National People's Congress; yet no amendment shall contravene the established basic policies of the People's Republic of China regarding Hong Kong (article 159), and these policies have been elaborated by the Chinese Government in the Sino-British Joint Declaration (as stated in the Preamble to the Basic Law). Similarly, article 11 restricts the power of the legislature of the Special Administrative Region in a corresponding way. In times of war or turmoil beyond regional control, relevant national laws may be applied in the Region pursuant to article 18; but the same article makes it clear that additions to the list of national laws applying in the Region, which list appears in Annex III, are confined to laws relating to defence 
and foreign affairs and other matters outside the specified regional autonomy. In harmony with this are the special provisions of article 18 concerning affairs which are the responsibility of the Central People's Government, or concerning the relationship between the Central Authorities and the Region. The regional Courts have no jurisdiction over acts of State such as defence and foreign affairs (article 19); but that is no whit surprising; and the meaning and scope of the limitation would fall for judicial interpretation if necessary although on questions of fact involved the Chief Executive's certificate will be conclusive. The Special Administrative Region is to enact laws on its own to prohibit acts of sedition and the like and political activities by or ties with foreign political organisations or bodies (article 23); but these laws presumably could not derogate from rights such as freedom from arbitrary arrest and the right to a fair trial (article 87).

Manifestly, it would be wholly inappropriate to attempt this evening any more detailed essay in interpretation. What can fairly be said is that in its basic guarantees of human rights, the Special Administrative Region enjoys a code, devised by duly accredited representatives of the People's Republic of China and the United Kingdom, capable of placing Hong Kong among or at least close to the leading countries of the world in the human rights field.

The long-term influence of the Basic Law in the world could be immense. Its impact may well not be limited to the fifty years. It could endure until and beyond the time next century when, as Lee Kuan Yew of Singapore has recently predicted, China will overtake the United States in terms of gross national product. In the same breath that elder statesman predicted that the weight of the world balance will shift from the Atlantic to the Pacific. History will not necessarily follow quite that path: no one can be prescient enough to make a definitive forecast. But the prospect cannot be dismissed. In the judicial field the functions of the Hong Kong Courts, epitomised by the constitutional role of the Court of Final Appeal but extending throughout the whole judicial structure, may be seen as a pioneering bridge between western and eastern legal systems. At least I like to think so.

There is a crucial addendum with which to conclude. Traffic over the bridge should not be one way. While western law is entrenched for fifty years, in the course of time eastern influences will make their contribution. Thus the traditional Confucian emphasis on the family as a unit, which is compatible with western culture, seems likely to endure. As to what may ultimately emerge as a synthesis of systems, prediction would be rash. Without indulging in it, I mention a few cardinal principles which could commend themselves as fitting in any evolved civilised legal system, taking as examples the fields of administrative law, contract and tort or delict. 
In administrative law, and in particular judicial review of discretionary administrative decisions, it may be affirmed that a concrete administrative act will not be accepted as lawful if it deviates from the objective of the relevant legislation, or is not based on relevant considerations, or is obviously unfair. The governing principle of tort law should be that there is civil liability where the actor through fault interferes with the property or person of another. And contract law should have at its heart the idea that civil activities must be carried out in accordance with the principles of voluntariness, fairness, exchange of equivalent values, honesty and good faith. I have taken the language of those propositions in those three fields from related sources. First, the Administrative Litigation Law of the People's Republic of China; second, the General Principles of Civil Law of the People's Republic of China; third, another article of the same General Principles. They are part of the massive reformulation of Chinese law dating from the later nineteen-seventies.

In the practical implementation of such principles, it is doubtless the case that China has quite a long way to go. But their proclaiming alone is of enormous significance. In some respects their terminology represents even an advance on the current state of the common law of English-speaking countries. It is cogent evidence that, very gradually but inevitably, mankind is moving towards a common law of the world. It will be a privilege to be a part-time member of a Hong Kong judiciary which, while cementing the rule of law here, may contribute significantly to that process.

\section{LE RÔLE DU JUGE DANS UNE SOCIÉTÉ EN ÉVOLUTION}

Cet article écrit par l'un des plus influents juristes de ces vingt derniéres années en Nouvelle Zélande (il a présidé pendant plus de dix ans la Court of Appeal de Nouvelle Zélande et est actuellement membre du House of Lords à Londres), definit avec pertinence le rôle du juge dans la société et plus particulièrement dans les pays de la Common Law.

L'observateur non averti, aurait a priori tendance à considerer que dans ce systeme juridique en particulier, le role du juge n'est pas que de "faire" le droit mais aussi de façonner par ses décisions, la société. Cette thèse est soutenue par une grande partie de la doctrine et des juges.

Lord Cooke of Thorndon quant à lui ne partage pas entièrement cette analyse. Il considère en effet que dans la réalité d'autres éléments influent de manière plus importantes sur les mutations de la société. Il soutient que le juge remplit avant tout un rôle de révelateur et d'équilibre de la société. Intégrité et impartialité demeurent les premières et seules véritables qualités requises d'un juge. 
Il ajoute que même Lord Denning, quintessence des qualités reconnues à un juge de la Common Law et souvent taxé de réformateur de la société, n'a fait qu'appliquer scrupuleusement la régle du "precedent", et ce non pas pour modifier la vie des gens en général mais pour assurer aux justiciables, une justice en adéquation avec les circonstances de leurs vies. Un tel résultat, conclut-il ne peut être atteint qu'en ayant une approche extensive de l'ensemble des principes dégagés par la Common Law et pas seulement en Angleterre. En effet dès lors qu'aucun systême juridique, même parmi les plus développés, ne peut se targer de pouvoir répondre avec certitude aux attentes des justiciables, l'auteur précise qu'il n'est pas approprié que les repères jurisprudentiels des juges se limitent exclusivement aux principes dégagés par les decisions des juridictions anglaises. Devront être considérées toutes décisions qui émanent des juridictions qui se réclament de la Common Law. Ce faisant, on tendra vers l'application de ce que l'auteur appele les principes la "common law of the world". Lord Cooke of Thorndon relève que ce phénomême n'est pas en soit particulierement nouveau, et c'est ainsi que le recours à des principes de droit plus généraux, souvent dégagés par la pratique ou des conventions internationales, est pratique courante en matière commerciale, où les juridictions anglaises appliquent la lex mercatoria, aussi connue sous le vocable "des principes géneraux du droit du commerce international". Il en va de même dans une moindre mesure, les droits de l'homme.

A l'appui de son analyse, Lord Cooke of Thorndon, s'intèresse au cas de Hong Kong dont il relève que les articles 8 et 18 de la "Basic Law of Hong Kong" ouvrent la possibilité aux juges de Hong Kong d'utiliser l'ensemble des décisions des juridictions de la Common Law, et ce sans limitation. 


\section{(1998) 28 VUWLR}

